\title{
Welfare Reform and Lone Mothers' Employment in the US
}

\author{
Jane Waldfogel \\ Sandra K. Danziger \\ Sheldon Danziger \\ Kristin Seefeldt
}

\section{Contents}

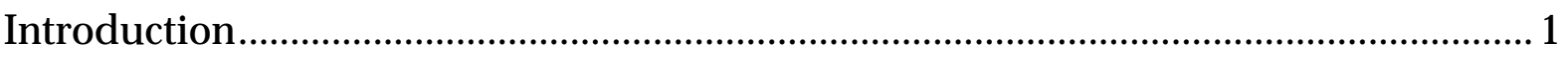

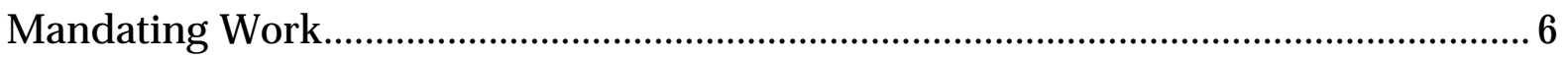

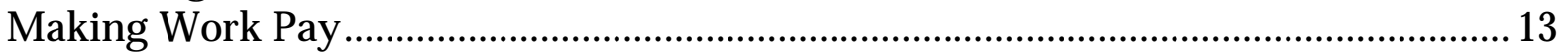

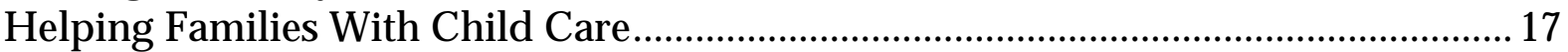

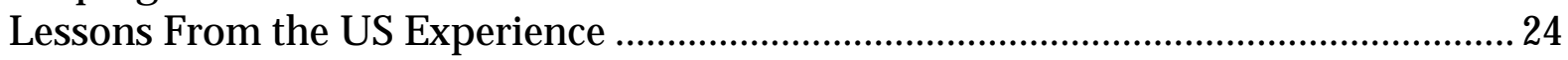

CASEpaper 47

June 2001
Centre for Analysis of Social Exclusion

London School of Economics

Houghton Street

London WC2A 2AE

CASE enquiries - tel: 02079556679 


\section{Centre for Analysis of Social Exclusion}

The ESRC Research Centre for Analysis of Social Exclusion (CASE) was established in October 1997 with funding from the Economic and Social Research Council. It is located within the Suntory and Toyota International Centres for Economics and Related Disciplines (STICERD) at the London School of Economics and Political Science, and benefits from support from STICERD. It is directed by Howard Glennerster, John Hills, Kathleen Kiernan, Julian Le Grand, Anne Power and Carol Propper.

Our Discussion Paper series is available free of charge. We also produce summaries of our research in CASEbriefs, and reports from various conferences and activities in CASEreports. To subscribe to the CASEpaper series, or for further information on the work of the Centre and our seminar series, please contact the Centre Administrator, Jane Dickson, on:

$\begin{array}{ll}\text { Telephone: } & \text { UK+20 7955 6679 } \\ \text { Fax: } & \text { UK+20 7955 6951 } \\ \text { Email: } & \text { j.dickson@lse.ac.uk } \\ \text { Web site: } & \text { http://sticerd.lse.ac.uk/Case }\end{array}$

(C) Jane Waldfogel

Sandra K Danziger

Sheldon Danziger

Kristin Seefeldt

All rights reserved. Short sections of text, not to exceed two paragraphs, may be quoted without explicit permission provided that full credit, including $(\odot$ notice, is given to the source. 


\section{Editorial Note and Acknowledgements}

This paper was prepared as the US case study for a conference on "Lone Parents and Employment", held in Bath, England, October 26-27 ${ }^{\text {th }}, 2000$ and is forthcoming in Lone Parents, Employment and Social Policy: Crossnational comparisons (Jane Millar and Karen Rowlingson, editors) to be published by Policy Press. This research was supported in part by grants from the Ford Foundation and the Joyce Foundation. We are grateful to Elizabeth Inez Johnson for help gathering data on state welfare and child care programs, to Gina Adams for helpful conversations about child care policies, and to Maria Cancian and Jane Millar for helpful comments on an earlier draft. We are also grateful to the Center for Analysis of Social Exclusion at the London School of Economics where Waldfogel and the Danzigers were visitors when this paper was prepared.

Jane Waldfogel (jw205@columbia.edu) is Associate Professor of Social Work and Public Affairs at Columbia University School of Social Work and a research associate at CASE. Sandra K Danziger (sandrakd@umich.edu) is Associate Professor of Social Work and Director of the Program on Poverty and Social Welfare Policy at the University of Michigan. Sheldon Danziger (sheldond@umich.edu) is Henry J. Meyer Collegiate Professor of Social Work and Public Policy and Director of the Center on Poverty Risk and Mental Health at the University of Michigan. Kristin Seefeldt (kseef@umich.edu) is Senior Research Associate at the Program on Poverty and Social Welfare Policy at the University of Michigan. 


\section{Abstract}

The Personal Responsibility and Work Opportunity Reconciliation Act (PRWORA) of 1996 represents a dramatic change in the US welfare state. One of its key goals was to move lone mothers, even those with young children, from welfare to work. Early evidence suggests that, in concert with a strong economy, progress has been made - welfare caseloads have fallen dramatically and the employment rates of lone mothers have increased substantially.

In addition to the federal reforms, state level welfare reforms played an important role prior to 1996 and are playing an even more important role subsequent to 1996 as PRWORA gives states unprecedented flexibility in designing and implementing their welfare systems. In this paper, we examine some key state-level reforms, using evidence from selected states, to illustrate the three major types of policies used in the US to move lone mothers from welfare to work: mandating work (Michigan); making work pay (Michigan and Minnesota); and helping families with child care (Illinois). We conclude that each of these policies has a role to play in moving lone mothers from welfare to work, but that further policies are needed if the US is to also to do a better job of reducing child poverty.

JEL numbers: I3, J00

Keywords: welfare, lone mothers, employment 


\section{Introduction}

An increasing share of children in the US are living with lone mothers. In 1998, 23 percent of children under the age of 18 lived with a lone mother, up from 18 percent in 1980 and 8 percent in 1960 (see Table 1). Although there are differences in the extent of lone parenthood across racial and ethnic groups, the share of children living with lone mothers has risen in all groups: from 1980 to 1998, the share of children living with a lone mother rose from 14 to 18 percent for whites, from 44 to 51 percent for African-Americans, and from 20 to 27 percent for Hispanics (see Table 2). ${ }^{1}$

\section{Table 1: Living Arrangements of US Children Under Age 18, 1960 to 1998}

\begin{tabular}{ccc}
\hline \hline Year & Percent living with lone mother & $\begin{array}{c}\text { Percent living with never-married } \\
\text { mother }\end{array}$ \\
\hline 1960 & 8.0 & 0.4 \\
1970 & 10.8 & 0.8 \\
1980 & 18.0 & 2.9 \\
1990 & 21.6 & 7.6 \\
1998 & 23.0 & 9.0 \\
\hline \hline
\end{tabular}

Source: 1996 Green Book, Appendix G; US Census Bureau, Statistical Abstract of the United States: 1999, Table No. 83.

The share of children whose mothers have never been married has grown more rapidly (see Tables 1 and 2). In 1998, 9 percent of all children lived with never married mothers, three times the 2.9 percent rate in 1980 and more than twenty times the 0.4 percent rate in 1960 . Between 1980 and 1998, the share of children living with never married mothers rose from 1 to 5 percent among whites, from 13 to 32 percent among blacks, and from 4 to 12 percent among Hispanics. By 1998, 39

1 In the US, a child is a person below the age of 18 , and a lone mother is a mother whose marital status is either never married or previously married (i.e., divorced, separated, or widowed). Thus, included in the count of lone mothers are women who may be cohabiting. 
percent of children living with lone mothers were living with never married mothers.

\section{Table 2: Living Arrangements of Children by Racial/Ethnic Group, 1980 to 1998}

\begin{tabular}{lcc}
\hline \hline Year & $\begin{array}{c}\text { Percent living with lone } \\
\text { mother }\end{array}$ & $\begin{array}{c}\text { Percent living with never- } \\
\text { married mother }\end{array}$ \\
\hline White & & \\
1980 & 14 & 1 \\
1990 & 16 & 3 \\
1998 & 18 & 5 \\
African American & & \\
1980 & 44 & 13 \\
1990 & 51 & 27 \\
1998 & 51 & 32 \\
Hispanic & & \\
1980 & 20 & 4 \\
1990 & 27 & 8 \\
1998 & 27 & 12 \\
\hline \hline
\end{tabular}

Source: US Census Bureau, Statistical Abstract of the United States: 1999, Table No. 83.

Lone mothers have historically had a higher labor force participation rate than married mothers (Burtless, 2000). However, their participation rate has varied by marital status (see Figure 1). Until recently, never married mothers' participation rate was lower than that of previously married mothers (and lower than that of married mothers). Figure 1 shows an increase in the participation rate of lone mothers in the late 1990s, with a particularly sharp rise for never married mothers after the mid-1990s; their participation rate now slightly exceeds that of married mothers.

Lone mother families have high poverty rates. In 1999, the rate for children living in lone mother families was 42 percent, as compared to 17 percent for all families with children (US Bureau of the Census, 2000).

These high child poverty rates are often attributed to the American social welfare system which provides a more limited range of benefits than other Western industrialized nations and relies to a larger extent on means-tested and targeted, rather than universal, benefits (Katz, 1996, p. $\mathrm{x})$. For instance, the US has no universal child benefit or allowance, no 
universal public health insurance, and no benefit for non-disabled individuals who are out of work unless they have sufficient recent work experience.

Figure 1: Labor Force Participation Rates of Women with Children, 1960 to 1998 (data from US Bureau of the Census, 1999, Table No. 659)

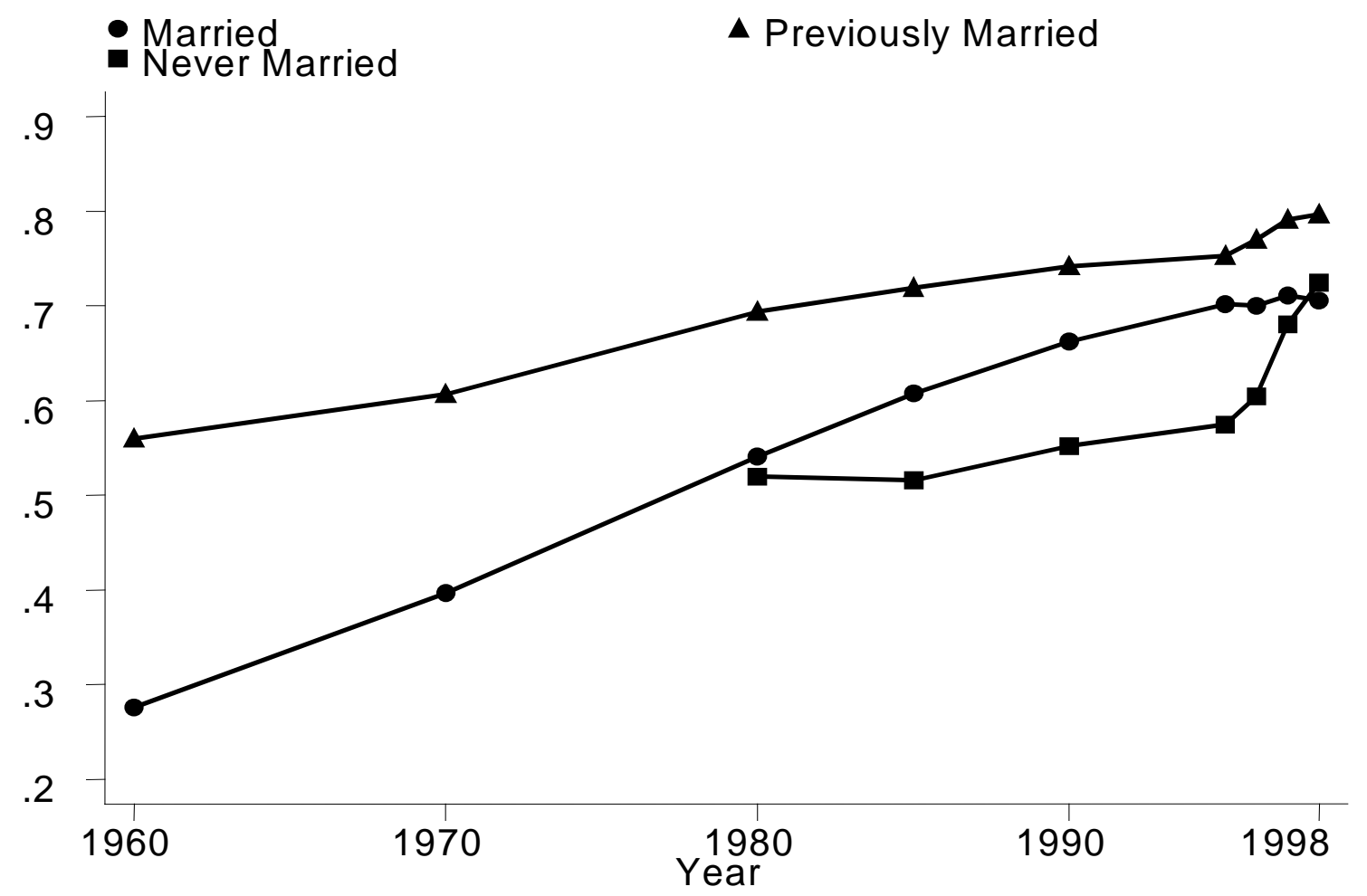

Three federal entitlement programs have been particularly important for the economic well-being of lone mother families. The first, Aid to Families with Dependent Children (AFDC), was designed for lone mother families (but later extended to two-parent families with an unemployed breadwinner). Until 1996, AFDC was an entitlement program, available to any family meeting the eligibility criteria which consisted of having low income and assets (until recently, no work or work-related activity was required). Payment levels, set by states, have varied widely by state and over time, but have tended to be low; in no state and year have AFDC benefits been sufficient to raise family incomes above the poverty line. A second federal entitlement program, Food Stamps, provides coupons for purchasing food to low-income individuals and families. Single-mother families receiving AFDC are automatically eligible for Food Stamps. In states with low AFDC benefit levels, Food Stamps play an important role in raising family incomes, although still not above the poverty line. A third federal entitlement, 
Medicaid, provides health insurance coverage to low-income individuals and families. In addition, there are a few smaller entitlement programs in which some lone-mother families participate (for instance, the Supplemental Security Income program for disabled individuals).

A number of discretionary programs also provide support to some lone-mother families. The Women, Infants, and Children program provides food coupons for low-income pregnant women and women with infants; various housing assistance programs provide rent subsidies or places in public housing for low-income families; and the Head Start program, discussed further below, provides pre-school education to children from low-income families.

The 1990s saw major changes in US welfare policies. At the national level, the Personal Responsibility and Work Opportunity Reconciliation Act of 1996 (PRWORA) ended the federal entitlement to cash assistance and replaced the previously open-ended funding for the AFDC program with capped block grant funding for a new time-limited cash assistance program, called Temporary Assistance to Needy Families (TANF). PRWORA sought to reduce welfare dependency by mandating work or employment-related activities as a condition of receiving welfare, even for lone mothers with small children. It gave states the autonomy to change program rules, including reforms that make combining welfare and work more attractive, and greatly expanded funding for child care for women engaging in employmentrelated activities, combining welfare with work, or leaving welfare for work (for a review of PRWORA's provisions, see Pavetti, 2000).

As federal welfare reform was being implemented, other federal reforms designed to make work more attractive for low-income single mothers were passed. The Earned Income Tax Credit (EITC), greatly expanded in 1993, is an important source of income for women leaving welfare for work. The federal minimum wage was raised in 1993, and health insurance benefits were extended to more low-income children through the 1997 Children's Health Insurance Program (CHIP). By the late 1990s, in most states, a lone mother would be financially better off working than remaining a non-working welfare recipient - the welfare trap had been sprung.

Welfare reforms at the state level have been even more farreaching. The impetus for federal reform came from state experiments that followed a previous welfare reform, the Family Support Act of 1988. A "waiver" process allowed states to seek permission to make fundamental program changes, such as imposing time limits and requiring work. Waivers began under the Bush administration and 
accelerated during the Clinton administration. By 1996, 46 states had been granted waivers.

After PRWORA passed, states took advantage of the new flexibility in TANF. For instance, while the federal law sets a five-year time limit for receipt of cash assistance, states may set shorter time limits. Most adopted the federal lifetime limit, but practices vary widely. For example, Tennessee maintains a five-year cap; it also terminates benefits after 18 months of receipt and does not allow families to reapply for assistance until another three months have passed. Another 16 states set time limits shorter than 60 months, ranging from 21 months in Connecticut to 48 months in Florida and Georgia. Less than 10 states plan to provide assistance beyond federal limits, although nearly all states have extension and exemption policies to the time limit (Gallagher et al., 1998). Likewise, while the federal law requires recipients to work within two years of welfare receipt, 20 states (plus the District of Columbia) require engagement in work or a work-related activity at the time they apply for assistance or within the first three months of receipt (National Governors' Association Center for Best Practices, 1999).

States must impose financial penalties - "sanctions" - for recipients who do not comply with the work requirements. These penalties range from immediate withdrawal of the family's full benefits (used by 16 states), to withdrawal of a portion of the family's benefits (12 states plus the District of Columbia), to gradual withdrawal of benefits (22 states) (US General Accounting Office, 2000). Seven states impose "lifetime" sanctions when recipients are in continued non-compliance such sanctions function like the time limits, but with recipients potentially terminated sooner. Sanctions may be affecting more families than the time limits.

These reforms were designed to move lone mothers into work by mandating work, making work pay, and helping with child care and the evidence suggests that they did just that. Between 1994 and 1999, the national welfare caseload was reduced by half, from 5 million cases to just 2.5 million, and recipients as a percentage of the US population fell from 5.5 to 2.3 percent (US Department of Health and Human Services, 2000). Over the same period, the labor force participation of all lone mothers increased by 10 percentage points (see Figure 1); the participation of never married mothers (the group of lone mothers most likely be have been on welfare) increased more than 15 points (from under 50 percent in 1990 to 65 percent by 1998). By 1997, the participation rate of never married mothers with pre-school age children exceeded that of married mothers with pre-school age children 
for the first time in the thirty-plus years that such statistics have been published; and the participation rate of all lone mothers exceeded that of married mothers for the first time since 1987 (Burtless, 2000).

Although the strong economy played a role, analysts agree that welfare reform was responsible for a substantial part of this increased employment (see, Danziger, ed., 1999). McKernan et al. (2000) tested the impact of ten state welfare policies on the employment rate of lone mothers and found that eight - raising hours of work requirements, reducing days of assistance before work requirement, reducing maximum months of benefits, increasing percent of benefits lost on first sanction, increasing months of transitional child care benefits, excluding the value of a vehicle from asset limits, raising the total asset limit, and changing the way housing assistance was treated - significantly increased lone mothers' employment but had no effect on the employment of single women without children (a group that should not have been affected by welfare reforms).

This evidence suggests that state level reforms contributed to the increased lone mothers' employment in the 1990s, although the increases would have been smaller if unemployment rates had been higher and if the minimum wage and EITC had not been increased. Therefore, we now examine some key state-level reforms, using evidence from selected states to illustrate the three major types of policies that have been used in the US to move lone mothers from welfare to work: mandating work (Michigan); making work pay (Michigan and Minnesota); and helping families with child care (Illinois).

These kinds of policies are complementary. A strategy to move women from welfare to work and out of poverty will be most effective if it combines elements from all three. We consider them separately in the sections that follow because states treat these as distinct policy areas and because this framework facilitates comparison with different policies in other countries. Although our focus is on the impact of welfare reform on lone mothers' employment, these policies may also affect child and family well-being. We briefly consider those issues as well.

\section{Mandating Work}

Prior to the 1996 reform, there were many exemptions from participation in work and training activities. Now, nearly all recipients must engage in "work activities" within two years of receiving assistance. Furthermore, states must meet work participation requirements-each 
year, an increasingly larger share of the caseload must work. 'Work' is defined as subsidized or unsubsidized employment, community service, on-the-job training, participation in job search or job search readiness activities (limited to 6 weeks in a year and no more than 4 weeks consecutively per participant), or participation in short-term vocational training. ${ }^{2}$

States have also adopted policies to make work more attractive to recipients. Prior to PRWORA, after four months of work, recipients could expect nearly a dollar reduction in benefits for every dollar earned. Now states can set their own policies. A number have expanded this "earned income disregard," allowing recipients to keep some of their benefits as earnings increase. (We return to this issue in the section, "Making Work Pay".)

Overall, states now have more discretion in designing TANF programs than they did under AFDC. This flexibility is constrained to some extent by federal work requirements and by bureaucratic inertia. Most states have adopted a "Work First" approach to move recipients into the labor force. Such programs assume that finding a job and developing work skills through direct experience - rather than participating in education and training - is the best strategy for finding work.

Some states have intensified efforts to divert applicants from receiving cash welfare and entering the welfare rolls. This practice, called diversion, may be accomplished through: 1) providing one-time financial assistance; 2) requiring mandatory job search as a condition of eligibility; and/or 3) linking applicants to other services or resources. Three-fifths of states use diversion activities, with lump sum payments and/or mandatory upfront job search being the most common (Maloy et al., 1998). An applicant accepting a lump sum payment is ineligible to receive TANF for some specified period. Mandatory job search prior to eligibility determination seeks to direct job-ready applicants into work. Referring applicants to other services in lieu of cash benefits is driven by beliefs that cash assistance should be a last resort and that services provide a better way of promoting work.

2 No more than 20 percent of the caseload can participate in vocational training and count toward the 'work' participation rate. 


\section{The Importance of Implementation}

The policies enumerated thus far are written into state law or policy manuals. How policies are implemented is determined by decisions made by those carrying out the day-to-day work. The increased state flexibility, coupled with the emphasis on work, has transformed the role of the welfare office and the functions of staff from providing benefits to supporting work. Welfare office staff now have greater discretion than prior to 1996. How that discretion gets used has an enormous effect on clients. In some states, the probability of being sanctioned varies significantly by local office (Fein \& Wang, 1999). The definition of "noncompliance" may also matter. For example, in Michigan, a client not cooperating with the Work First program may have her grant reduced. If that same client is working and quits working, her grant may be terminated. In Wisconsin, for each hour a client does not participate in an assigned activity, her check is reduced by the hourly minimum wage. If she does not participate at all, she may receive no grant. In states requiring job search as part of the application process, the amount of assistance given to applicants could affect entry into the system; if applicants are provided little or no guidance during their search, they may give up and never become eligible for cash assistance.

The trend toward contracting out for services has accelerated since PRWORA. Many states have privatized parts of the welfare system, particularly the job search and placement functions. Greater privatization could have far-reaching consequences for clients. Concerns about accountability, withholding services (e.g., due to profit motive), and dissimilar services across providers are amplified when a private agency is involved.

\section{Recipient Process in Michigan}

In Michigan, families apply for TANF, called the Family Independence Program (FIP), at one of more than 100 Family Independence Agency (FIA) offices across the state. Most offices take applications on a walk-in basis in the morning hours. The applicant, typically a lone mother, receives a combined application form (for food stamps, medical assistance, child care and cash benefits) and must show documentation for sources of income, employment, citizenship and birth certificates, school registration and local address. She must cooperate with child support requirements and help identify the father of her children. The applicant is usually seen by the Family Independence Specialist (FIS) worker who goes over eligibility information, discusses policies and rules, and focuses on requirements of the Work First program. 
Within two weeks, she must attend a Work First orientation session run jointly by the welfare agency and Work First program staff, where program rules and work requirements are detailed. Availability of child care and employment and training options are mentioned during orientation. Attendance at orientation is part of the application process; if she does not attend, she will not receive cash assistance. If she attends orientation and the first day of Work First activities and is financially eligible, the FIS opens her case.

The client and her FIS also develop a Personal Responsibility Plan and Family Contract, outlining her goals and responsibilities and what the program will provide to help meet those goals. The plan may include goals such as finding employment through Work First, or returning to school for further training. This plan is initiated within the first two months of her receiving assistance and may be modified, particularly when the client meets with her worker.

State policy requires that FIS workers make quarterly home visits. If the recipient falls into sanction status (for noncompliance), home visits are on a monthly basis. The home call is designated to build a trusting relationship between the client and the worker so that the client will discuss family concerns. The workers rely on informal interaction and client self-disclosure to uncover any employment barriers. Formal diagnostic or structured assessment tools are not used.

Unless the client is already employed for at least 20 hours a week at the minimum wage (or more, depending on the ages of her children and her marital status), she must attend a Work First program. She will be exempt from the work requirement only if she has a disabling health problem or cares for a family member with a health problem, has a newborn less than 3 months of age, is a teen parent attending school, or is over age 65. During 1997, about 20 percent of the caseload was deferred from work requirements and between 36 and 56 percent of recipients reported earnings from work, with the remainder (between one-half and one-quarter) of cases expected to be searching for work. By 1999, the proportion of the caseload deferred averaged 42 percent, growing each month. This is due to continued declines in the caseload. ${ }^{3}$ The proportion of cases with earnings averaged around 33 percent.

Once in Work First, the types of assistance and the sequencing of services she would receive vary, depending on the program model

3 The number of deferred cases has remained around 32,000 while the total caseload declined from approximately 155,000 at the beginning of 1997 to about 77,000 at the end of 1999 . 
chosen by the local provider. In 1998, for the most part, Michigan's 83 Work First programs conform to one of four different approaches that vary along a continuum of formal services. 4

At one end of the spectrum are 20 programs in which the client participates for approximately one week in structured "job search readiness" activities, such as resume and letter preparation and mock interviews. She would also attend workshops on topics relevant for job retention and life skills, such as anger management and budgeting. At the same time or during the next week, she would search for work. To assist her job search, she has access to free telephones to call employers, newspaper ads, and lists of job openings culled from the state employment agency. Additionally, program staff may call employers on her behalf, supply her with leads on jobs, bring employers to the Work First site for interviews, and/or take her for interviews with potential employers.

The largest group of Work First programs, three-eighths, provide either formal job search workshops or specialized direction and support in job search, but not both. Ten programs offer workshops on a variety of topics, covering job seeking, retention and life skills, but provide less staff assistance during the direct job search phase. The other 21 offer workshops related to job search skills or provide workshop activities only to clients who do not find a job within the first week or two of being in the program. However, in these programs, the agency provides a full array of specialized job search services, linking directly clients with employers.

Another one quarter of the providers offer primarily instruction on job search techniques in the workshops. The agency supplies job postings and access to job listings, but clients are responsible for making direct contacts with employers and arrangements for interviews.

Finally, 5 of the 83 programs offer few structured services. They assist clients with resume preparation and provide listings of open jobs, but group workshops are rare, and job search efforts are primarily the client's responsibility. These programs are in rural areas, so group activities may not be feasible.

These latter two types of Work First programs reflect a belief that it is best for a client to find a job on her own. Two reasons are cited: clients may be more likely to stay in jobs they found for themselves, as opposed to ones "given" to them by staff, and clients need to learn the

4 Two programs could not be categorized using this scheme. 
skills of job search, so that they can conduct future searches. The other program models, in which staff assist clients during the job search, assume that clients have certain disadvantages (in their ability to conduct a job search and/or their qualifications) compared to other job seekers and therefore need more assistance in securing employment. 5

Clients unable to find work within four weeks may still be required to search for work or may be placed in a work experience position or a vocational training class. If, however, a woman drops out of the program or is otherwise determined non-compliant, her case will be sent back to FIA for review. If the caseworker finds that she does not have a legitimate reason for not cooperating, her benefits will be reduced by 25 percent. After four months, if she continues to be out of compliance, her case will be closed. If she is a new applicant, she must demonstrate compliance within the first 60 days of case opening or she can be dropped from the rolls immediately.

If this client gets a job, Work First will check at 30 day intervals to see if she remains employed, up to the $90^{\text {th }}$ day on the job or for as long as the client remains on assistance. If she loses her job and is still on cash assistance, she will be re-referred by her FIS worker to Work First and start the process of job search again.

\section{Assessment of Work First}

Michigan's Work First program is similar to that of many of the states. Local administrators in Michigan generally express support for the mandatory labor force attachment model (Danziger and Seefeldt, 2000), but they raise concerns about how well this program model works for recipients. Work First managers identify both structural and personal impediments to success. However, few programs systematically evaluate recipients for depression, domestic violence, or other personal problems, much less provide referrals or access to service providers to treat the problems (for a review of barriers to work, see Danziger et al., 2000). Some problems which managers cite as impediments to employment that are also common among recipients - transportation needs, child care problems, low sense of personal mastery and lack of job skills - are sometimes targeted for services. Most programs provide child care subsidies, along with vouchers for public transportation or vans; lack of work experience, self esteem and soft skills are the target of

5 Due to the manner in which data is kept in Michigan (regionally, rather than by Work First agency) we are unable to determine if one of the four Work First program models is more effective at moving clients into jobs. 
some workshops and job search strategies. In contrast, health and mental health problems are not usually assessed or treated, and educational pursuits are not generally supported as alternatives to or substitutes for employment. As welfare rolls continue to decline, it is likely that the proportion of the caseload with these problems will increase.

Given the needs of welfare recipients and current program design, in what directions might the Work First model be improved? First, applicants would be assessed and referred for services for health and mental health problems and perhaps would receive treatment prior to job search. Because managers realize that such problems make people hard to employ, some recipients might be allowed to fulfill their work requirement by participating in treatment. ${ }^{6}$ In at least two states, Oregon and Utah, welfare-to-work programs are staffed with mental health professionals who provide counseling services and referrals to treatment programs (Johnson and Meckstroth, 1998).

Second, clients with few work skills, little prior work experience, and educational deficiencies might be referred for more intensive training. While long-term investments in education and training are not allowable under PRWORA, participation in a short-term job training is allowed. In Michigan, the Work First program now allows clients to participate in "condensed vocational training," no longer than six months in duration, or to combine work with training or participation in high school equivalency (GED) preparation. However, GED preparation does not count toward work participation rates (except in the case of teen-aged recipients).

Programs also could provide financial assistance for clients' auto purchases and repairs. A new federal program "Access to Jobs and Reverse Commute Program," operated through the US Department of Transportation, has the goal of improving transportation options for welfare recipients.

Mandating work and job search, in the context of the economic boom of the 1990s, moved many recipients into the work force. However, many have moved into low skill, low paying jobs. The reforms to the mandated work approach suggested here would, if successful, do a better job in promoting the broader goals of job retention, job growth, and increased family well-being.

6 While these activities do not count toward the federal work participation requirement, states are not precluded from assigning clients to non-work activities. 


\section{Making Work Pay}

In late 2000, the entitlement to cash assistance had ended and welfare rolls had declined more than most analysts had predicted when the reform was passed. PRWORA did not, however, transform the cashbased safety net of AFDC into an effective work-based safety net there is no guarantee that a lone mother who seeks work but cannot find a job will receive any cash assistance or any opportunity to work in return for assistance.

As mentioned above, however, PRWORA gave states great latitude in setting welfare rules related to how the earnings of welfare recipients affect their cash assistance payments. As a result, more than 40 states have changed their rules to do more to "make work pay." Most have eliminated the "welfare trap" that previously existed-i.e. between 1981 and 1996, most single mothers experienced a decline in net income if they went from being a nonworking welfare recipient to a part-time worker at the minimum wage.

This disincentive resulted from the fact that once a welfare recipient worked for four months, benefits were reduced by one dollar for every dollar earned. And, many women lost Medicaid when they went to work. Thus, single mothers were faced with the choice of receiving welfare or working, and many "chose" welfare, both because it allowed them to stay home with their children, and because work did not pay.

PRWORA's strict work requirements no longer allow a single mother to chose to stay home with her children, but the law no longer prevents a state from supplementing her low earnings with cash assistance. For example, in Michigan, a woman must work once her youngest child is three months or take part in work-related activities for at least 20 hours per week-she can not choose to stay at home with her baby. However, Michigan now allows her to keep her first \$200 in monthly earnings and 20 percent of the remainder; California has a $\$ 225$ disregard and allows her to keep 50 percent of the remainder; Illinois disregards 67 percent of her earnings (Gallagher et al., 1998). In Michigan, a single mother of two children who does not work can receive a maximum cash benefit of $\$ 489$ per month. If she works 30 hours per week at the minimum wage ( $\$ 5.15$ per hour), she will earn about $\$ 670$ per month. Under the new earnings disregard she will receive $\$ 113$ per month in cash assistance in addition to her earnings. 
In addition to welfare reform, there has been a major change outside of welfare that also increases the financial rewards of work. The Earned Income Tax Credit (EITC), enacted in 1975, provides all working poor families with a refundable income tax credit (i.e., the family receives a payment from the Internal Revenue Service if the credit due exceeds the income tax owed). The EITC raises the effective wage of low-income families, is available to both one- and two-parent families, and does not require them to apply for welfare. The maximum annual EITC for a poor family was $\$ 953$ in 1990. After several legislative increases, the maximum EITC for families with two or more children was $\$ 3,756$ in 1998 ; it was $\$ 2,272$ for families with one child. A single mother with two children earning $\$ 670$ per month would receive an EITC of about $\$ 3,000$ per year.

In addition, in 1986 a woman leaving welfare for work and her children would have lost medical coverage, but by 1997, her children would remain eligible for government paid health insurance because of a post-PRWORA program, the Children's Health Insurance Program.

Danziger, Heflin and Corcoran (2001) document that it pays to move from welfare to work in Michigan. They analyze data from a sample of about 700 women who received welfare in February 1997 and were interviewed in Fall 1997 and Fall 1998. Respondents reported, for the month before the interview, work hours, earnings, welfare receipt, and income from a variety of sources. Respondents were also asked about work-related child care and transportation expenses. In addition to the reported income sources, the study imputed the value of federal and state income taxes, the Earned Income Tax Credit (EITC) and the employee's share of Social Security taxes.

The authors classified the women by their work/welfare status wage-reliant women were those who reported earnings, but no cash welfare income (43.6 percent of the sample at the second wave, 1998); combiners were those who reported both earnings and cash welfare in the interview month (27.1 percent of the sample); welfare-reliant mothers were those who received welfare but no earnings (20.4 percent); the final category included those who were neither working nor receiving cash welfare (8.9 percent).

When Danziger, Heflin and Corcoran take all these income sources and the EITC into account and subtract taxes and work-related child care and transportation expenses, they find that the average net monthly income was $\$ 1,677$ for wage-reliant mothers, $\$ 1,449$ for combiners, $\$ 1,027$ for welfare-reliant mothers and $\$ 1,178$ for those not working and not receiving welfare. Working mothers have, on average, higher 
incomes than welfare mothers. Wage-reliant mothers had an average net income 63 percent higher than that of welfare reliant mothers, and women combining work and welfare had a net income 41 percent higher than that of the welfare-reliant. Thus, in Michigan it does now pay to move from welfare to work. ${ }^{7}$

Nonetheless, poverty remains high for these single mothers after welfare reform - the monthly poverty rate for all respondents was 53.5 percent (the official US 1998 federal poverty threshold for a household of that size is divided by 12); 38.4 percent of wage-reliant mothers, 53.0 percent of combiners, 83.3 percent of welfare-reliant mothers and 68 percent of those who were neither working nor received welfare were poor. The good news is that poverty is much lower for workers than for nonworkers. The bad news is that poverty remains very high for workers, and the annual poverty rate would be even higher than these numbers indicate because most wage-reliant women do not work, and hence do not earn this much, in every month.

Similar results are evident from the Minnesota Family Investment Program (MFIP), which was evaluated in a randomized demonstration by the Manpower Demonstration Research Corporation (this summary is based on Berlin, 2000). For long-term welfare recipients, MFIP increased the welfare benefit by 20 percent for those who took a job and allowed recipients to keep 38 percent of every dollar earned. It also required long-term recipients who were not working at least 30 hours per week to participate in job search or other work requirements. Thus, MFIP anticipated the kind of welfare reform that has evolved in most states after 1996 - increased work requirements to boost work effort and increased work incentives to make work pay.

According to the MDRC evaluation (Knox et al., 2000), the percentage of single-parent long-term program participants who worked in an average quarter (in the first 9 quarters after the program began) was about 50 percent, compared to 37 percent of the controls. The poverty rate was about 75 percent for the treatment group, but 85

$7 \quad$ Detailed monthly income data for all respondents for February 1997 when the sample was drawn are not available. At that time, all respondents were receiving cash welfare, and about $40 \%$ were working, and the variance in monthly income was likely to be a lot smaller than it was at the Fall 1998 interview. In work in progress, the authors attempt to correct for selection effects and still find that those who have moved from welfare to work have greater income increases than those who remain as nonworking welfare recipients. 
percent for the controls. Unlike the data from the Michigan sample, these data do not include income from other household earners, an estimated value of taxes and the earned income tax credit, or a measure of work-related expenses. But, the results are similar - welfare reforms that increase work requirements and work incentives improve the situation of welfare recipients, but more must be done if poverty is to be reduced.

Thus, in a booming economy, most welfare recipients can find some work but many do not escape poverty. The economic incentives now in place are in accord with the goals of policy planners - on average, wage-reliant mothers and those combining work and welfare are economically better off than welfare-reliant mothers. These results also suggest that more attention should be paid to factors that prevent those remaining welfare-reliant from going to work. The new economic incentives and the increased pressure to leave welfare make it unlikely that many lone mothers are rejecting work and choosing to stay on welfare. Rather, many of them have problems, such as poor physical and/or mental health or lack of job skills, which prevent them from getting and keeping jobs even when unemployment rates are low (S. K. Danziger et al., 2000).

In the aftermath of welfare reform, many welfare-reliant mothers are at high risk of losing cash assistance benefits due to sanctions and/or impending time limits. And, in many states, mothers combining work and welfare are also at risk of losing benefits due to time limits. Now that it is economically beneficial to move from welfare to work, there remains a need for additional policies to make work pay enough so that a greater percentage of working mothers can escape poverty and for enhanced policies to help welfare-reliant mothers move into regular jobs or into subsidized employment.

The law now requires lone parents who have no serious impairments to take personal responsibility and look for work. However, PRWORA absolves the state of any responsibility — even if a woman diligently searches for work without finding a job, her cash assistance can be terminated. At a minimum, lone mothers should be offered an opportunity to perform community service in return for continued cash assistance. A more costly option, but one that would have a greater antipoverty impact, would be to provide low-wage public service jobs of last resort. Welfare recipients who were willing to work could then combine wages with the Earned Income Tax Credit and support their families even when there was little employer demand for their skills. 
If we are to reduce poverty as well as the welfare caseload, we must demonstrate greater willingness to spend public funds to complete the task of turning a cash-based safety net into a work-oriented safety net. For recipients with the most extensive personal problems as mentioned in the previous section, this requires an expansion of social service and treatment programs, but also merits experimentation with supported work programs, where participants work in closely supervised settings.

\section{Helping Families With Child Care}

The federal government and states have greatly expanded their investment in child care since PRWORA was enacted. The Act consolidated federal funding into a child care and development block grant (CCDBG); 20 billion dollars were allocated for the period 1997 to 2002, reflecting a 25 percent increase (an additional four billion dollars) over the spending provided under prior legislation (US House of Representatives, Committee on Ways and Means, 1998). States can increase spending further by shifting federal funds out of their TANF block grants. Additionally, states were given new flexibility in designing subsidy systems.

As a result, state child care systems are now more varied than ever before. In this section, we use data from Illinois to illustrate one state's policies. Illinois is a large state that has greatly increased child care spending since PRWORA, but still faces challenges in meeting the child care needs of lone mothers. Illinois is not representative of other states. As we shall see below, it is one of few states to guarantee child care assistance to low-income families; it has made a somewhat higher level of investment in child care than other states; and it is one of few states that contract directly with child care providers. (For an overview of child care developments in all states, see Blank and Poersch, 2000.)

Policies that help families find and pay for adequate non-parental child care can facilitate the employment of lone mothers. All else equal, mothers facing lower child care costs are more likely to be employed, particularly low-income or single mothers (Han and Waldfogel, 2000). Low-income single mothers also report being more likely to work when care is more available (Mason and Kuhlthau, 1992) and when they are more satisfied with the quality of care (Meyers, 1993). Problems with child care can lead lone mothers to leave jobs and can also adversely affect attendance, work hours, and career advancement. 
In addition, the quality of child care may influence child outcomes. When child care is of high quality, children gain cognitively and socioemotionally (NICHD Early Child Care Research Network, 1999 and in press). However, the quality of care in most settings in the US is only poor to fair, with children from low-income or single-mother families the least likely to attend high-quality day care centers, unless they are fortunate enough to get a subsidized space in a private day care center or in an especially good Head Start center (Head Start is the federal government's early education program for low-income three and four year olds) (Galinsky et al., 1994). Thus, it is important to consider both how to make child care more affordable and accessible and how to improve its quality.

Policies to make child care affordable and accessible include: providing subsidies; giving families choices to use the subsidies; expanding the supply of care, so that care is available at the hours families need it; and integrating welfare and non-welfare subsidies, so that families do not lose their subsidy when they leave welfare for work. There are also ways to enhance the quality of care. We consider these aspects of child care policy in Illinois. 


\section{Providing Subsidies}

Every state sets its own policies for child care subsidies. Typically, states set eligibility criteria (including a family income cut-off, expressed as an amount in dollars, or a percentage of the poverty line or of the state's median income, and a requirement that the parent be working or participating in education or training) and then provide subsidies to a subset of eligible families, depending on the availability of funds. Prior to PRWORA, welfare recipients or former welfare recipients had priority, but this is no longer required under the federal law (although it is still often the case in practice).

Illinois had this kind of policy until 1997. Now, any family whose income falls below 50 percent of the state's median income (and who meets the other eligibility criteria) is guaranteed a child care subsidy. To make the guarantee feasible, Illinois dropped its family income cut-off, from $\$ 26,230$ to $\$ 21,819$ for a family of three (Adams and Schulman, 1998), and thus has a relatively low income cut-off (50 percent of state median income and roughly 155 percent of the 1999 federal poverty line) compared to other states (whose cut-offs range 50 to 85 percent of the state median income and from 125 to 255 percent of the poverty line) (State Policy Documentation Project, 1999). Illinois recently implicitly raised its cut-off by disregarding the first 10 percent of a family's earnings in computing income eligibility.

Illinois is one of only 5 states that guarantee a subsidy to lowincome families. The others are Iowa, whose cut-off is 155 percent of the federal poverty line; Kansas, at 185 percent; Rhode Island, at 225 percent; and Wisconsin, at 165 percent (State Policy Documentation Project, 1999).

The guarantee provides a powerful message to low-income women with children - "There are no waiting lists. All families who fall within the income categories for their family size are eligible" ("Affordable Child Care" brochure, Illinois Department of Human Services (DHS)). As the public becomes more aware of this guarantee, the share of eligible families, many of whom will never have received welfare, using subsidies will likely increase.

Unfortunately, only limited information on subsidy use is currently available. A study of welfare leavers, interviewed in late 1998, found that 36 percent received a child care subsidy, but that 31 percent reported problems paying for child care (Julnes and Halter, 1999). We do not know what share of other low-income women are receiving subsidies or how the rates of subsidy receipt have changed over time. Evidence from other states suggests that rates of subsidy use have been 
surprisingly low, possibly because women are not receiving information about subsidies or think that they are not eligible, find applying too difficult, or perceive that waiting lists are too long (Meyers and Heintze, 1999; US Department of Health and Human Services, Child Care Bureau, 1999).

In addition to eligibility criteria, the rate at which providers are reimbursed affects the use of subsidies. If a provider accepts a statesubsidized client, it must accept this price for its services (although if its regular rate is higher, it may in some states ask the parent to make up the difference). Illinois now pays up to the $75^{\text {th }}$ percentile of the "market rate," similar to most other states. In fiscal year 1999, 81 percent of child care providers in Illinois said that they would accept a subsidized client, up from 60 percent the prior year (Ramsburg and Montanelli, 2000) when its rate had been as low as the 43rd percentile of the market rate in some communities (Adams and Schulman, 1998).

States also set co-payment policies. Consistent with standard practice, Illinois requires a family to make a small co-payment, which varies according to the family's income. Co-payments for one child range from $\$ 1$ per week for the poorest families to $\$ 31$ per week for those with incomes close to the income cut-off for eligibles. Copayments do not vary according to the cost of the care. Child advocates consider this important, as it does not create incentives for families to choose lower cost forms of care.

As welfare caseloads have fallen and as more single mothers have gone to work, Illinois' spending on child care and the numbers of children served have grown dramatically. Total spending on child care grew from $\$ 187$ million in fiscal year 1995 to a projected $\$ 656$ million in fiscal year 2001, while the numbers of children served each month grew from 65,000 to a projected 218,000 over the same time period (see Table $3)$. Although data on the share of children in low-income lone mother families being served are not available, the increase must be large as well. 
Table 3: Child Care Spending and Numbers of Children Served in Illinois, 1995 to 2001

\begin{tabular}{lcc}
\hline \hline Year & Annual spending (in \$, millions) & Children served (per month) \\
\hline 1995 & 187 & 65,000 \\
1996 & 226 & 82,000 \\
1997 & 263 & 92,000 \\
1998 & 307 & 115,000 \\
1999 & 448 & 154,000 \\
2000 & 591 & 195,000 \\
2001 & 656 & 218,000 \\
\hline \hline
\end{tabular}

Source: "DHS Child Care," DHS Division of Transitional Services, www.state.il.us/agency/dhs.budget/overview/transsvc.pdf.

\section{Giving Families Choices}

Illinois, like other states, reimburses child care arranged by families, as well as care delivered by contracted providers. Most subsidized families select a provider and then work with a local "child care resource and referral agency" (a non-profit organization that helps families locate child care and that in Illinois also administers the subsidy) to set up the reimbursement. Parents can choose any type of care - a child care center, family day care home, or care provided in their own home or in a relative's home - and any specific provider, so long as space is available and the provider meets licensing requirements. Providers bill the state once a month, and checks are issued about three weeks later. About one in six subsidized families use care delivered by providers (typically, large day care centers) that have contracts with the state to provide a certain number of slots at an agreed-upon rate. (Illinois is unusual in this regard, as states have tended to move away from contracts to voucher type systems).

Illinois notes, "This dual system provides families with the freedom to choose from a variety of child care settings to best meet the needs of both parents and children" ("Child Care" brochure, Illinois DHS, 2000). However, choices are constrained by the supply of care available. If there are shortages of care of particular types or for children of particular ages or at particular hours, allowing parents to choose may not ensure that parents' and children's needs are met. There may also be shortages in particular neighborhoods or communities (Julnes and Halter, 1999). 


\section{Expanding Supply}

Illinois, like most states, has historically had a limited supply of certain types of care (Adams and Schulman, 1998), especially care for infants and toddlers, and care during night and weekend hours. Demand for these types of care has grown since welfare reform. For instance, the number of families seeking toddler care doubled from 1997 to 1999, while the number of families requesting weekend care increased by more than 50 percent (Ramsburg and Montanelli, 2000). To address supply shortfalls, the state now offers incentives to providers. For instance, licensed providers who make 25 percent of their slots available to children under two, and who reserve half of those slots for subsidized children, are reimbursed at a 10 percent higher rate for the children they serve under the age of two. Incentives are also offered to licensed providers who agree to stay open at nights and on weekends.

\section{Integrating Welfare and Non-Welfare Services}

There is a tension in child care policy between targetting services to welfare recipients and making services more universally available, so that families are not denied benefits simply because they leave welfare or did not receive welfare in the first place. Prior to PRWORA, federal policy required states to guarantee child care to working recipients; other families could be served only to the extent that funds remained. PRWORA gave states the flexibility to design their own policies. Many states continue to give current and former welfare recipients priority, thus setting up competition between them and low-income families who have not been welfare recipients. Illinois, as noted above, guarantees a subsidy to any family whose income falls below 50 percent of the state's median income, without regard to welfare receipt. And because the subsidies are administered by child care resource and referral agencies or contracted providers, applicants need not have any contact with the welfare department. Indeed, non-welfare families now make up the majority of subsidy recipients - their share increased from 46 to 57 percent from 1998 to 1999 (Ramsburg and Montanelli, 2000).

\section{Quality Enhancements}

Although the quality of care in many settings is poor or mediocre (Galinsky et al., 1994; Helburn (ed.), 1995; NICHD Early Child Care Research Network, 1999), little is known about the quality of care being used by the children of women leaving welfare. Few studies of welfare leavers have measured child care quality (Fuller and Kagan, 2000). With 
regard to the type of care, women leaving welfare for work are more likely to use informal care (such as care by a friend or relative) than formal care (such as care in a day care center or licensed day care home); and women who do not have a subsidy are the least likely to use centerbased care. However, we do not know whether this reflects the fact that they could not afford center-based care, or that they preferred to use a friend or relative.

Data on the quality and type of care being used in Illinois are sparse as well. Most subsidy recipients make their own arrangements, with only about one sixth using contracted centers. About two-thirds of subsidy recipients use informal types of care, with 41 percent using relatives and 25 percent using in-home care (Piecyk, Collins, and Kreader, 1999).

Illinois is attempting to improve child care quality through increased funding. In fiscal year 2000, Illinois spent \$27 million on quality enhancement efforts, up from $\$ 7$ million two years earlier ("Child Care", Illinois DHS, 2000). A major quality enhancement effort involves making Head Start more accessible to the children of employed mothers. Head Start has long provided fairly high-quality care for children of low-income lone mothers. However, because Head Start programs are typically part-day programs and are not open year-round, using them has been a problem for employed mothers. Illinois is spending nearly $\$ 8$ million each year to enable selected Head Start programs to open full-day and full-year and focus on the children of employed mothers. Illinois is also spending about $\$ 1.5$ million in fiscal year 2001 on a program to monitor the child care delivered by relatives or provided in-home (this kind of care, which is exempt from licensing, serves about two-thirds of the children funded by subsidies). Illinois will also spend \$2.4 million in fiscal year 2001 (up from \$1.4 million the prior year) on the TEACH (Teacher Education and Compensation Helps) program (imported from North Carolina), which offers family or centerbased child care providers funding to attend college, and financial incentives to stay on as providers after they complete the program.

\section{Assessing Illinois' Experience with Child Care}

Illinois' experience suggests that a state can develop a more coherent policy and play a more active role in the child care market. Illinois has greatly increased spending to lower costs to make more care available, and to improve the quality of care. It is one of only a few states that guarantee a child care subsidy to low-income families. To support this policy, Illinois has greatly increased state funding for child care but it 
has also targeted its funding to families below a relatively low income cut-off.

Unfortunately, we do not know as much as we would like about how effective these efforts are. Lone mothers' employment has increased rapidly in Illinois and in other states, but we do not know how important child care has been in driving that increase. Few studies have examined the impact of child care policies on employment after welfare reform, and they have not examined specific child care policies or impacts on child outcomes. Bainbridge, Meyers, and Waldfogel (2000) find that increased government expenditures on child care subsidies account for only a small share of the increase in lone mothers' weekly employment post welfare reform

\section{Lessons From the US Experience}

Welfare reform has been more successful than most policy analysts anticipated when the 1996 Act was signed. Bolstered by a strong economy and a surge of federal funding to the states, welfare reform has contributed to large declines in the welfare rolls and increased work among lone mothers and has been modestly successful in raising incomes for those who work. We illustrate what selected states have done in three key areas - mandating work, making work pay, and helping with child care - that contribute to these successes to date.

However, many lone mothers, who are not able to find and keep jobs, are worse off financially as a result of the reforms. Many others are no better off financially - they have simply moved from the ranks of the welfare poor to the working poor. In many states, a single mother with a pre-school age child is expected to work at least 30 hours per week, at a minimum wage job with only a modest amount of child care subsidy and EITC and health insurance only for her children.

Thus, the picture from the states is mixed. Welfare to work programs, programs to make work pay, and child care subsidies have contributed to the increased employment of lone mothers. However, lone mothers and their children remain at high risk of poverty and hardship.

These results suggest that countries that are willing to end the entitlement to cash assistance, and accept some increases in hardship, can look to the US as a model for increasing the employment of lone mothers. Other countries, however, might derive a different lesson and choose to both increase employment and reduce financial hardship. 
Following this path requires a range of policies and services, not yet available in the US, that would more completely transform a cash-based safety net into a work-based safety net. For the most part, even though the American states have, since PRWORA, done a better job making work pay and helping families with child care, they have not done enough to provide work opportunities and social services for those who have been unable to find steady work in the best labor market in three decades. 


\section{References}

Adams, Gina and Karen Schulman (1998). "Illinois: Child Care Challenges." Washington, DC: Children's Defense Fund.

Bainbridge, Jay, Marcia Meyers, and Jane Waldfogel (2000). "Child Care Reform and the Employment of Single Mothers." Paper presented at the Association for Public Policy Analysis and Management Conference, Seattle, Washington, November 2, 2000.

Berlin, Gordon L. 2000. Encouraging Work, Reducing Poverty: The Impact of Work Incentive Programs. New York: Manpower Demonstration Research Corporation.

Blank, Helen and Nicole Oxendine Poersch (2000). "State Developments in Child Care and Early Education 1999". Washington, DC: Children's Defense Fund.

Burtless, Gary (2000). “Can the Labor Market Absorb Three Million Welfare Recipients?" Mimeo, Brookings Institution.

Danziger, Sandra K., Mary Corcoran, Sheldon Danziger, Colleen Heflin, Ariel Kalil, Judith Levine, Daniel Rosen, Kristin Seefeldt, Kristine Siefert, and Richard Tolman (2000). "Barriers to the Employment of Welfare Recipients." In R. Cherry and W. Rodgers (eds.) Prosperity for All? The Economic Boom and African Americans. New York: Russell Sage Foundation.

Danziger, Sandra K. and Kristin S. Seefeldt 2000. "Ending Welfare Through Work First: Manager and Client Views." Families in Society, 81 (6): 593-604.

Danziger, Sheldon H. (ed). (1999). Economic Conditions and Welfare Reform. Kalamazoo, MI: Upjohn Institute for Employment Research.

Danziger, Sheldon, Heflin, Colleen and Corcoran, Mary (2001). "Does it Pay to Move from Welfare to Work?" University of Michigan working paper. www.ssw.umich.edu/poverty/pubs.html

Fein, David, Wang Lee. 1999. Carrying and Using the Stick: Financial Sanctions in Delaware's A Better Chance Program. Boston, MA: Abt Associates Inc.

Fuller, Bruce and Sharon Lynn Kagan (2000). Remember the Children: Mothers Balance Work and Child Care under Welfare Reform. Berkeley, CA: University of California at Berkeley Graduate School of Education. 
Galinsky, Ellen, Carollee Howes, S. Kontos, and Marybeth Shinn (1994). The Study of Children in Family and Relative Care. New York: Families and Work Institute.

Gallagher Jerome, Megan Gallagher, Kevin Perese, Susan Schreiber, and Keith Watson. 1998. One Year After Federal Welfare Reform: A Description of State Temporary Assistance for Needy Families (TANF) Decisions as of October 1997, Assessing the New Federalism, Occasional paper no. 6, The Urban Institute, Washington, D.C.

Han, Wenjui and Jane Waldfogel (2000). "Child Care Costs, Regulations, and the Employment of Married and Unmarried Mothers". Forthcoming in Social Science Quarterly.

Helburn, Suzanne (ed.) (1995). Cost, Quality, and Child Outcomes in Child Care Centers: Technical Report. Denver: Department of Economics, Center for Research in Economic and Social Policy, University of Colorado at Denver.

Illinois Department of Human Services (DHS) (2000). "Affordable Child Care" (brochure). Available from www.state.il.us/agency/dhs.

Illinois Department of Human Services (DHS) (2000). "Child Care" (brochure). Available from www.state.il.us/agency/dhs.

Johnson, Amy and Alicia Meckstroth (1998). Ancillary Services to Support Welfare to Work. Princeton, NJ: Mathematica Policy Research, Inc.

Julnes, George and Anthony Halter (1999). "When Families Leave Welfare Behind: Illinois Families in Transition. First Survey Findings." Institute for Public Affairs, University of Illinois at Springfield and School of Social Work, University of Illinois at Urbana-Champaign.

Katz, Michael (1996). In the Shadow of the Poorhouse: A Social History of Welfare in America. New York: Basic Books.

Knox, Virginia, Cynthia Miller, and Lisa Gennetian. (2000). Reforming Welfare and Rewarding Work: A Summary of the Final Report on the Minnesota Family Investment Program. New York: Manpower Demonstration Research Corporation.

Maloy Kathleen, LaDonna Pavetti, Peter Shin, Julie Darnell, Lea Scarpulla-Nolan (1998). Description and Assessment of State Approaches to Diversion Programs and Activities Under Welfare Reform: An Interim Report of the Findings of the First Phase of the Research. Assistant Secretary for Planning and Evaluation, 
Administration for Children and Families, US Department of Health and Human Services.

Mason, Karen and Karent Kuhlthau (1992). "The Perceived Impact of Child Care Costs on Women's Labor Supply and Fertility." Demography, 29, 523-543.

McKernan, Signe-Mary, Robert Lerman, Nancy Pindus, and Jesse Valente (2000). "The Relationship between Metropolitan and NonMetropolitan Locations, Changing Welfare Policies, and the Employment of Single Mothers". Revised version of paper presented at the Joint Center for Poverty Research Conference on Rural Dimensions of Welfare Reform, Washington, D.C., May 4-5, 2000.

Meyers, Marcia K. (1993). "Child Care in JOBS Employment and Training Program: What Difference Does Quality Make?" Journal of Marriage and the Family, 55(August), 767-783.

Meyers, Marcia and Theresa Heintze (1999). "The Child Care Subsidy Shortfall: Is the Subsidy System Working for Those Working Their Way Off Welfare?" Social Service Review, 73(1), 37-64.

National Governors' Association Center for Best Practices (1999). Round Two Summary of Selected Elements of State Programs for Temporary Assistance for Needy Families. Washington, D.C.: NGA.

NICHD Early Child Care Research Network (1999). “Child Outcomes When Child-Care Center Classes Meet Recommended Standards for Quality." American Journal of Public Health, 89, 1072-1077.

NICHD Early Child Care Research Network (in press). "The Relation of Child Care to Cognitive and Language Development: Results from the NICHD Study of Early Child Care." Forthcoming in Child Development.

Pavetti, Donna (2000). "Welfare Policy in Transition: Redefining the Social Contract for Poor Citizen Families with Children and Immigrants." Paper presented at "Conference on Understanding Poverty", Madison, Wisconsin, May 2000.

Piecyk, Jessica Brickman, Ann Collins, and J. Lee Kreader (1998). "Patterns and Growth of Child Care Voucher Use by Families Connected to Cash Assistance in Illinois and Maryland." Mimeo, National Center for Children in Poverty. 
Ramsburg, Dawn and Dale S. Montanelli (2000). "1999 Report on Illinois Child Care." Springfield, IL: Illinois Department of Human Services.

State Policy Documentation Project (1999). "Child Care Provision after Leaving Cash Assistance." www.spdp.org.

US Bureau of the Census (1999). Statistical Abstract of the United States 1999. Washington, DC: US Government Printing Office.

US Bureau of the Census (2000). Poverty in the United States 1999. P-60210. Washington, DC: US Government Printing Office.

US Department of Health and Human Services (2000). "Change in Welfare Caseloads Since Enactment of New Welfare Law: Total TANF Recipients by State." Washington, DC: Author.

US Department of Health and Human Services, Child Care Bureau (1999). "Access to Child Care for Low-Income Working Families." Washington, DC: Author.

US General Accounting Office. (2000). Welfare Reform: State Sanction Policies and Number of Families Affected. GAO/HEHS-00-44. Washington, D.C.: US Government Printing Office.

US House of Representatives, Committee on Ways and Means (1996). 1996 Green Book: Background Material and Data on Programs Within the Jurisdiction of the Committee on Ways and Means. Washington, DC: US Government Printing Office.

US House of Representatives, Committee on Ways and Means (1998). 1998 Green Book: Background Material and Data on Programs Within the Jurisdiction of the Committee on Ways and Means. www.waysandmeans.house.gov/publica.htm. 